\title{
TEACHING AND TEACHER EDUCATION
}

\section{Teacher educators and student-directed learning}

\author{
Mieke Lunenberg ${ }^{\mathrm{a}, *}$, Fred A.J. Korthagen ${ }^{\mathrm{b}}$ \\ ${ }^{a}$ Institute for Teacher Education and Educational Practice, Vrije Universiteit, De Boelelaan 1115, 1081 HV Amsterdam, The Netherlands \\ ${ }^{\mathrm{b}}$ IVLOS, Utrecht University, Postbox 80127, 3508 TC Utrecht, The Netherlands
}

Received 7 December 2000; received in revised form 7 June 2002; accepted 8 July 2002

\begin{abstract}
This article describes the results of a study on the views of teacher educators, and the way these views are expressed in practice. The study focuses on views of learning and teaching that can promote a shift from teacher educator-directed learning to student-directed learning. We found that teacher educators did not always 'teach as they preach', especially on aspects that distinguish the profession of teacher educators from the profession of teachers. The article concludes by discussing the influence of the findings with regard to promoting a shift from teacher educator-directed learning to student-directed learning and by giving some suggestion for further research.
\end{abstract}

(C) 2002 Elsevier Science Ltd. All rights reserved.

Keywords: Teacher education; Teaching methods; Learning strategies

\section{Introduction}

In literature on education, the constructivist perspective seems to enjoy considerable popularity, although voices criticizing the constructivist approach for being one-sided can also be heard. Gijselaers (2000) states that the introduction of constructivist-based education stems from the conviction that it is impossible to teach pupils or students for the rest of their lives. He concludes that, true or not, this conviction increases the importance of studying teaching and learning processes. In this article we will do so, with an emphasis on teaching and learning processes in teacher education. In the mainstream constructivist approach to learning and teaching, learning is

\footnotetext{
*Corresponding author. Tel.: + 31-0-20-4449-222; fax: +310-20 4449-250.

E-mail address: ml.lunenberg@ido.vu.nl (M. Lunenberg).
}

considered an active process in which the learner builds up personal knowledge representations that are the results of his or her learning experiences. As a consequence, the emphasis in constructivistbased education is on the activities of the learner (Brown, Collins, \& Duguid, 1989). Both Zimmerman (1990) and Claxton (1996) argue that the learning process should be organized in such a way that learners can take responsibility for their own learning processes. Pupils and students should be able to estimate their own levels and to plan and adjust their learning processes accordingly. Thus student-directed learning has become an important theme in educational theory and practice (Cobb \& Bowles, 1999). In an overview, Richardson (1999) states that student-directed learning and curricula that are student-centered have become the focal points for constructivist-based educational practices. These changes have consequences for the teaching profession. 
In the last few years, we have carried out several studies to discover how teachers cope with these changes (for an extensive report of one of the studies, see: Lunenberg \& Volman, 1999, in this journal).

The most important findings of these studies are:

- often teachers are not clear about their expectations of pupils' learning; pupils' images of what teachers expect from them differ from the actual expectations of teachers;

- teachers do not always seem capable of helping pupils to construct knowledge and to put it into practice; pupils focus on intake of knowledge and see knowledge mostly as an abstraction that does not have anything to do with either daily life or future profession;

- teachers do not always find the right balance between directing the learning processes of pupils and giving them space for self-direction; often pupils have a feeling of either being constricted or abandoned;

- although teachers try to connect subject matter with pupils' personal interests and stimulate pupils to cooperate, pupils seldom recognize these intentions of their teachers.

All teachers involved in our studies were experienced teachers who graduated from teacher education years ago. So a reason for the disappointing findings may be that their teacher educators taught them according to traditional methods. This elicited the question of how student teachers are taught today. After all, in order to change educational practices it is necessary 'to break the circle' (Stofflett \& Stoddart, 1994) of traditionally trained teachers who teach in a traditional manner. It seems reasonable to expect that new educational practices will be introduced in teacher education. However, are teacher educators competent to do so?

Recently, more attention has been given to the competences of teacher educators. A good example of the growing attention paid to the competences of teacher educators is the introduction of professional standards. The Association of Teacher Educators in the USA (ATE) was the first professional organization to develop such stan- dards. After 3 years of work and several rounds of consultations, the ATE published a report on 'Certification of Teacher Educators' in 1995 (Houston, 1999). Europe was next. In Europe the Association of Teacher Educators in the Netherlands (VELON) took the lead and published a first draft of professional standards in 1999 (Dengerink \& Koster, 2000).

The Dutch standards focus on five groups of competences: subject competences, pedagogical and didactical competences, organizational competences, communication competences and competences for development and growth (Dengerink \& Koster, 2000). The description of these competences shows that a constructivist approach was an important source of inspiration. For example, the pedagogical and didactical competences are listed as coaching student teachers with different personal interests, making pedagogical and didactical choices explicit and discussing them with student teachers, and promoting reflection and realistic self-evaluation among student teachers.

Despite this growing attention to the functioning of teacher educators, research into the profession of teacher educators is still scarce (Korthagen \& Russell, 1995. For an overview see Korthagen, 2000). In the USA Ducharme (1993) showed how limited the knowledge that we have about the profession of teacher educators really is. In Europe the situation is not much different. In 1990 the results of a research project on teacher educators ordered by the European Council of Ministers of Education were reported. It concluded that there was 'an almost absence of structured training and supervision of teacher educators (European Journal of Teacher Education, 1990), partly due to the fact that a knowledge base for teacher education was lacking. Ten years later Buchberger, Campos, Kallos, and Stephenson (2000) draw the conclusion that there is still a lack of research, researchbased knowledge and validated practices.

In this article we report the results of a study that concentrates on the competences of five teacher educators, and especially on their ability to stimulate a shift from teacher educator-directed learning to student-directed learning. To study the competences of teacher educators, we also questioned and observed their student teachers. 
The leading question in this article is

Do teacher educators show the views, as well as the teaching actions, that promote a shift to studentdirected learning?

We chose to focus on case studies for two reasons. Firstly, this method is useful for carrying out in-depth studies in a still unexplored field. Our second reason was more practical in nature. We assumed that discussing the outcomes of case studies could help teacher educators rethink their own teacher education practices. This article focuses on the first reason. Our objective in this regard is to explain the contribution that our studies make to the body of knowledge in this field. We have already reported - in a previous study - how the outcomes of the case studies were received by the participating teacher educators (Lunenberg, 2000).

The structure of this article is as follows. In the next section, we describe the theoretical framework of the research study. We then explain the methodological approach and summarize the findings of the five case studies. The article concludes with a discussion section.

\section{Theoretical framework}

From our previous research on teachers and teaching methods we have derived three principles that can stimulate a shift from teacher educatordirected learning to student-directed learning. These are directly connected with the findings summarized in the introductory section.

The first principle concerns the images teacher educators have of student teachers and the images that student teachers have of themselves. Egan (1978) was the first to point out the 'be like me' phenomenon: teacher educators regard themselves as role models. Recently Wideen, Mayer-Smith, and Moon (1998) discussed the influence of this phenomenon on the development of and changes in teacher education. To educate teachers for the future, role models should be open to change. More specifically, Ten Dam $(1989,1995)$ found that the cognitive and social images of students and the extent to which these images correlate with the images the teachers have of the students, influence the learning process. Examples of cognitive characteristics are eagerness to learn, independence and concentration. Examples of social characteristics are openness, trust and carefulness.

A discrepancy between the teacher's and student's perception both decreases the student's selfesteem and increases the dropout risk. So, for promoting student-directed learning, the images teacher educators have of student teachers have to match with the images student teachers have of themselves. 1

Two other principles that can promote a shift from teacher educator-directed learning to student-directed learning have to do with the issues of learning orientations and mental models of teaching and learning. In line with researchers like Entwistle (1988), Dweck (1989), White \& Frederiksen (1989), and Marton (1990), Vermunt (1992, 1997) distinguishes four types of learning orientations and five types of mental models.

\section{The learning orientations are:}

- certificate-oriented: education is primarily a means to obtain a certificate or qualification;

- vocation-oriented: education is primarily a means to acquire skills for a specific occupation and to find a job;

- oriented towards personal interest: student teachers who have this orientation are motivated by their interest in the subject and their own personal development;

- ambivalent: student teachers who have this orientation have an insecure, hesitant attitude towards education and little confidence in their learning abilities.

Vermunt's studies show that a personal interest orientation is most typical of a student-directed learning style. He states that for a shift to studentdirected learning, it is important that the teaching and learning orientations of teacher educators correlate with those of the student teachers, andlor that teacher educators stimulate student teachers to

\footnotetext{
${ }^{1}$ This first principle differs from the principles two to five, because this first principle concerns characteristics of student teachers. The principles two to five all concern issues of teaching and learning.
} 
broaden their learning orientations, especially in the direction of a personal interest orientation.

This is the second principle in our study.

The mental models of teaching and learning are:

- intake of knowledge: learning is the acquisition of factual knowledge presented by the teacher, memorizing it and being able to reproduce it;

- construction of knowledge: learning is looking for connections, relating new subject matter to what is already known;

- use of knowledge: learning is being able to use subject matter;

- stimulating education: learning means to perform a broad range of learning activities, stimulated by the teacher;

- cooperation: learning is primarily achieved by working together.

The mental model of the construction of knowledge is most typical of a student-directed learning style. Following Vermunt, the third principle for the promotion of student-directed learning is that it is important that the mental models of teaching and learning used by teacher educators correlate with those used by student teachers andlor that teacher educators stimulate student teachers to broaden their mental models of learning, especially in the direction of construction of knowledge.

Besides these three principles, which emerged from our previous studies on teachers and their pupils, and are supported by the work of, among others, Ten Dam $(1989,1995)$ and Vermunt (1992, 1997), we also used two new principles in the present study, because the teacher education profession differs from the teaching profession in at least two important respects. The first of these additional principles has become known as the reflection principle. Whereas we may expect teachers to reflect on their daily practice, teacher educators should not only reflect on their teacher education practice, but must also develop the reflection competence of student teachers (Calderhead, 1987; Furlong \& Maynard, 1995). In other words, reflection should have a double significance for teacher educators. Van der Vaart and Lunenberg (1996; see also Vonk, 1995;
Lunenberg, 1999) found that, among other things, teacher educators should know how to use different reflection methods, such as writing a journal or drawing educational situations. They should also take into account the stage of development of the various student teachers and encourage them to reflect on different aspects of their daily practice and experiences, such as class management and differentiation among pupils, as well as on their future profession. We consider teaching student teachers to reflect regularly and variedly on different aspects of the teaching profession to be a fourth principle in promoting a shift from teacher educator-directed learning to student-directed learning.

Finally, we employ the congruence principle (see for example, Day, 1999; Korthagen, Kessels, Koster, Lagerwerf, \& Wubbels, 2001, p. 48): teacher educators not only teach a subject (teaching), but are also role models for teaching. In this respect their profession is different from, for example, doctors teaching medicine. While teaching, the doctors do not act as role models for practising medicine. It is not only important that teacher educators 'teach as they preach', but they should also explain their choices. Our assumption is that behaving as a role model and explaining pedagogical and didactical choices is a fifth principle in promoting a shift from teacher educator-directed learning to student-directed learning. A good example was given in this Journal by Wood and Geddis (1999). They describe a lecture by an experienced teacher educator who uses a metacommentary along with a modelling of effective teaching behaviour.

\section{Method}

\subsection{Design}

We carried out case studies on the daily practice of five teacher educators, working in a consortium of four teacher education institutes that cover most of the Christian teacher education for primary as well as secondary schools in the northern part of the Netherlands. The research 
instruments we used for collecting data were semistructured interviews and observations.

With these instruments we studied the degree to which the five principles, described in the previous section, were present in the views and teaching actions of teacher educators.

Our data analysis was a content analysis: we focused on qualitative data, using the theoretical principles formulated in our theoretical framework as the categories for analysing these data. (For an overview of types of analyses in case study research, see Yin, 1994; Cohen, Lawrence, \& Morrison, 2000.)

To enhance internal validity, we followed the guidelines for case study research established by such researchers as Miles and Huberman (1984), Yin (1994) and Merriam (1998). We applied different forms of triangulation:

- Multiple data sources: teacher educators, student teachers and teaching sessions;

- Different methods for collecting data: interviews and observations;

- A multi-member research team: five researchers carried out the case studies. Two trained researchers were assigned to each case study to prevent bias.

\subsection{Instruments}

\subsubsection{Interviews}

We used semi-structured interviews to establish the degree to which the images of the cognitive and social characteristics, the learning orientations, the mental models of teaching and learning, and the approaches to reflection of teacher educators corresponded with those of their student teachers. In each case, we interviewed the teacher educator and five of his/her student teachers, using a fivepart interview.

1. Part one of the interview sought to obtain some background information with questions about the learning (and teaching) history of the respondent. (See Section 4).

2. Part two of the interview focused on the cognitive and social images of the student teachers. Following Ten Dam (1989, 1995), these were assessed by asking both the teacher educators and their student teachers to rate pairs of opposite concepts on a scale from 1 to 4. We asked teacher educators, for instance, to rate the following item: "My students are open/ my students are reserved". The corresponding item for student teachers was: "I am open/I am reserved". $(1=$ open, $2=$ largely open, $3=$ largely reserved, $4=$ reserved). Our main objective in using these scales was not to collect quantitative data. Rather, we used them as interview prompts and instruments to structure our interviews. The rating questions were followed by open questions, which were intended to check, illuminate and give concrete form to the ratings. For example, we asked the teacher educators and student teachers to illustrate some of their responses to key statements from the questionnaire.

3. Part three of the interview concentrated on teaching and learning orientations. Following Vermunt (1992), these were measured by rating statements about learning on a scale of 1 to 4 . An example of these statements for teacher educators was: "It is important that my students get good marks". The corresponding statement for the student teachers was: "It is important to me to get good marks". $(1=\mathrm{I}$ disagree, $2=\mathrm{I}$ disagree largely, $3=\mathrm{I}$ agree largely, $4=\mathrm{I}$ agree). The ratings were used as an introduction to more open questions on the subject of teaching and learning orientations.

4. Part four of the interview examined mental models of teaching and learning (see also Vermunt, 1992). These were also measured by rating statements on a scale from 1 to 4 . An example of these statements for teacher educators was: "My students have to learn subject matter by heart". The corresponding statement for the student teachers was: "I repeat words and sentences to myself until I know them by heart". $(1=\mathrm{I}$ disagree, $2=\mathrm{I}$ disagree largely, $3=\mathrm{I}$ agree largely, $4=\mathrm{I}$ agree). Here too, the ratings were used to introduce more open questions on the subject of mental models of teaching and learning.

5. Part five of the interview examined the teacher educators' approaches to regular and varied reflection on different aspects of the teaching 
profession (Van der Vaart \& Lunenberg, 1996). We asked them to rate a number of statements on a scale from 1 to 3 . An example of these statements for teacher educators was: "I challenge my students on their ideas about pupils". In the interviews with the students we checked if the student teachers recognized these approaches by using corresponding statements: "My teacher educator challenges me on my ideas about pupils". (In this case, $1=$ seldom, $2=$ regularly, $3=$ often). Once again, the rating items were followed by open questions aimed at checking, illuminating and giving concrete form to the ratings.

We compared the interview results for each teacher educator with the interview results for his/ her student teachers and drew up an analysis of similarities and differences for the images, the teaching and learning orientations, the mental models, and the views on approaches to reflection.

\subsubsection{Observations}

We also examined the extent to which the images, orientations, mental models and approaches to reflection were expressed in the educational practices of the teacher educators. To this end, we observed the teacher educators while they were actually teaching and compared the interview results with our findings during observation. In each case study, we observed two teaching sessions involving the teacher educator concerned and a group of student teachers, including the student teachers we had interviewed. The observers worked with a prescribed format and a pre-tested list of areas of focal attention. We interpreted the findings from our observations as expressions of images, teaching and learning orientations, mental models and approaches to reflection. This method enabled us to establish the degree to which the teaching practices we observed manifested - or lacked - the images, orientations, mental models and approaches to reflection as found in the interviews.

During the observations, the congruence principle was an additional area of focal attention. We observed the extent to which each teacher educator functioned as a role model, and whether he or she explained his/her pedagogical and didactical choices to the student teachers.

\subsection{Data analysis}

For each case we compared the findings from the interviews, which reflected views (images, teaching and learning orientations, mental models, and views on approaches to reflection), with the findings from the observations (focusing on teaching and learning actions). We then drew up an analysis of consistencies and inconsistencies.

As mentioned above, our analysis was a content analysis: we focused on qualitative data, using the theoretical principles formulated in our theoretical framework as the categories for analysing these data. The first draft of each case study report was discussed with the teacher educator ('membercheck'; see Merriam, 1998). This gave the teacher educators the opportunity to correct factual mistakes, add information and offer alternative interpretations, if they wished.

Subsequent careful reflection by the researchers, functioning as 'critical friends' (Day, 1999) for each other, including weighting the credibility of alternative interpretations and considering patterns in the case results (pattern matching), was incorporated into a final case report, along with comments by the teacher educator.

Finally, we made an overview of the outcomes of the five cases. We used the outcomes of this overview to compare the findings from the individual cases with the common findings. For each of the five principles described in the previous section, we will present the main outcomes of the five case studies in Section 5, as well as the noteworthy results of the comparisons of the individual cases with the main outcomes.

\section{Introduction of the players}

The first case study involves Bill. $\mathrm{He}$ is in his mid-thirties and works as a teacher educator in physical education at a Teacher Education Institute for primary schools. His students are in the final stages of a 4-year teacher education course. 


\begin{tabular}{|l|l|l|l|l|}
\hline Name & Age & Type of education & Subject & $\begin{array}{l}\text { Stage/kind of course } \\
\text { observed }\end{array}$ \\
\hline Bill & mid-thirties & $\begin{array}{l}\text { TEI* for primary } \\
\text { schools }\end{array}$ & Physical education & $\begin{array}{l}\text { Final year of a four- } \\
\text { year course }\end{array}$ \\
\hline Irene & mid-fifties & $\begin{array}{l}\text { TEI* for secondary } \\
\text { schools }\end{array}$ & Modern languages & $\begin{array}{l}\text { One-year course } \\
\text { after finishing } \\
\text { university }\end{array}$ \\
\hline Rudolph & mid-forties & $\begin{array}{l}\text { TEI* for secondary } \\
\text { schools }\end{array}$ & Pedagogy & Refresher course \\
\hline Margaret & mid-fifties & $\begin{array}{l}\text { TEI* for primary } \\
\text { schools }\end{array}$ & Pedagogy & $\begin{array}{l}\text { Final year of a } \\
\text { condensed two-year } \\
\text { course }\end{array}$ \\
\hline Steven & late fifties & $\begin{array}{l}\text { TEI* for secondary } \\
\text { schools }\end{array}$ & Coaching/biology & $\begin{array}{l}\text { Final year of a four- } \\
\text { year course }\end{array}$ \\
\hline
\end{tabular}

* TEI $=$ Teacher Education Institute

Fig. 1.

They all have extensive practical experience in primary schools.

The teacher educator in the second case study is Irene. She is in her mid-fifties and works as a teacher educator in modern languages at a Teacher Education Institute for secondary schools. After finishing university, her students are following a 1year course to become a teacher. Each week they spend part of their time in a secondary school.

The teacher educator in the third case is Irene's colleague, Rudolph. $\mathrm{He}$ is in his mid-forties and has a degree in educational studies. He is following a 2-year course to become a certified supervisor. In the case study, he teaches a group of mature students who already have a degree but for one reason or another have never gone into teaching or who have not had any teaching experience for a long time. They all spend some time every week teaching in a secondary school.

The fourth case involves Margaret, a colleague of Bill's. She is in her mid-fifties and has a degree in educational studies. In this study, she is observed educating a group of mature students who want to become primary school teachers. The normal 4-year educational course has been condensed into 2 years for them. They are halfway through at the time of our data gathering and spend a number of days a week doing teaching practice in primary schools.

Steven is a teacher educator in his late fifties. He is a biologist. However, in this fifth case he is not educating biology student teachers, but coaching a group of students in their final practical training period. The students of this group are all working in schools for secondary vocational education and are hoping to graduate from their 4-year teacher education course within a few months.

In Fig. 1, the main characteristics of the five case studies are summarized.

\section{Findings}

\subsection{Images of cognitive and social characteristics}

Based on our first principle for promoting student-directed learning, we assessed whether the images that the five teacher educators had of the cognitive and social characteristics of their student teachers corresponded with the images the student teachers had of themselves. As mentioned before, examples of cognitive characteristics are eagerness to learn, independence and concentration. Examples of social characteristics are openness, trust and carefulness. Below we report the outcomes of the interviews and the observations.

\subsubsection{Interviews}

The images that the five teacher educators had of the cognitive and social characteristics of the student teachers generally concurred with the student teachers' images. Teacher educators as well as student teachers saw the student teachers as eager to learn, concentrated, open, trustworthy 
and careful. In four cases, the student teachers were slightly more positive than the teacher educators were; in the case of Margaret she was slightly more positive than her student teachers were.

However, the five teacher educators differed from their student teachers in their images of the student teachers' cognitive characteristic of independence: the teacher educators considered their student teachers more dependent learners than the student teachers themselves did.

\subsubsection{Observations}

The observations of the lessons confirmed the general findings of the interviews. The student teachers in the five cases were cognitively and socially involved in the lessons. An example of cognitive and an example of social involvement are:

- In one of Irene's lessons a student teacher starts a discussion about the lack of attention for idiom in school programs. The other student teachers react with arguments to support this statement or with examples that show that the statement is untrue.

- In a lesson of Margaret a student presents a problem: "I feel insecure. I have the feeling that my mentor keeps me down. He often points to the fact that I am a trainee and sometimes forgets that I prepared a lesson." The other students try to help: "Tell him" and "Do you know where your insecurity comes from?"

The observations also showed that the lessons of the five teacher educators were highly structured. Almost all student teachers seemed to function fairly well within the structure. This may explain the different images of the teacher educators and the student teachers with regard to the degree of independence in learning. On the one hand, teacher educators seemed to think that student teachers needed structure because of their lack of independent learning; on the other hand it seemed that this structure prevented student teachers experiencing dependency. Two examples:

- Bill, a teacher educator for primary school teachers, starts with a brief introduction, referring to the literature studied prior to this lesson. (...) Next he recreates a playground, a physical education classroom and a regular classroom within his own large gymnasium. He then assigns three different tasks to three separate groups: organize a playground game, organize a game for physical exercise in a physical education classroom and organize a game in a regular classroom. Two groups start well; the third needs Bill's support. A student in another group comments: "They need structure" (...).

- Margaret's group organizes its own meeting following the standard procedure of problemsteered education, to report on their preparations of and their practical experiences with philosophy lessons for young children. Margaret has the role of adviser. The chairperson starts with the question: "Who has found literature on creative philosophising?" After sharing findings the next question is how to define speculation and analysis. Margaret asks a student who doesn't seem very involved to answer this question. She steers the line of the following discussion and gives some examples. The group joins in (...).

In summary, we found the following factor that promotes a shift to student-directed learning:

- The views of the teacher educators generally match the views of their student teachers, and the observed practices, in relation to most of the student teachers' cognitive and social characteristics.

One factor that could hinder a shift to studentdirected learning is:

- The views of teacher educators mismatch the views of their student teachers regarding the student teachers' level of independent learning.

\subsection{Teaching and learning orientations}

Based on our second principle for promoting student-directed learning, we assessed the teaching and learning orientations of the teacher educators and their student teachers. We asked, for example, whether getting high marks is important or not (certificate orientation), if practical experiences are brought forward in lessons (vocational orientation), if attention is given to the career development of student teachers (orientation towards 
personal interest) and to what level teacher educators and student teachers have confidence in the learning capacities of student teachers (ambivalent).

\subsubsection{Interviews}

In the interviews, the five teacher educators and their student teachers appeared to be certificateand vocation-oriented. In the cases of Bill, Irene, Margaret and Steven the student teachers were also certificate- and vocation-oriented. The student teachers in Rudolph's group were slightly less certificate-oriented because, as they stated in the interviews, they were already graduates. Rudolph, however, thinks it is important for the self-esteem of his students to obtain the certificate.

We found interesting differences between some teacher educators and their student teachers with regard to personal interest-oriented learning. Three teacher educators, Irene, Steven and $\mathrm{Ru}-$ dolph, clearly stated that they considered vocation-oriented learning more important than personal interest-oriented learning. Bill and Margaret considered vocation-oriented learning and personal-oriented learning equally important. The student teachers in the five cases demonstrated an almost equal appreciation for both orientations. One student teacher's comment during an interview may explain the underlying reason: "My personal interests and my desire to prepare for a vocation complement each other."

The difference we found between the teacher educators and their student teachers in regard to the ambivalent orientation was also noteworthy. The five teacher educators told us in the interviews that they devoted a great deal of time and energy to teach students how to learn and to stimulate their self-confidence. Strangely enough, the student teachers in the five cases described themselves as being moderately to highly self-confident. As one stated, "Sometimes I get a little insecure, but I know I'll succeed in the end."

\subsubsection{Observations}

During observation, we encountered various examples of a certificate-oriented approach and numerous manifestations of a vocation-oriented approach. The observation report of one of the sessions involving Steven and his student teachers gives us an example of a certificate orientation:

- The session with Steven and his student teachers starts with a number of practical questions students have regarding the registration of credit points and so on.

Steven's student teachers, who are in the final stage of their practical training and are working almost full time, use part of the session with their teacher educator to make sure that their credits are being registered properly, because they want to graduate in a few month' time. We have found similar examples in the lessons of the other teacher educators.

Vocational orientation is evident in all the lessons observed. As we saw above, Bill recreates a playground, a physical education classroom and a regular primary school classroom within his own large gymnasium, and Margaret's student teachers report on their own preparations and practical experiences with philosophy lessons for young children.

- Irene discusses with her student teachers how to analyse the usefulness of learning methods. Irene's student teachers, for example, present their findings and Irene questions them ("Would you choose these methods?") and gives additional information ("This method is well known because of its possibilities to differentiate among pupils"). She also points to very practical aspects: "Did you weight these books? They are very heavy for young pupils."

- Rudolph asks his student teachers to analyse, in small groups, the degree of attention for differentiation in various learning methods. The discussion in the small groups is lively.

- Steven tries to use the daily experiences of his student teachers in secondary vocational education and translate them into the theoretical framework of Leary's Rose (a model for mapping interpersonal behaviour; Leary, 1957). Although the student teachers are not very enthusiastic at the start of the session, they become more involved later on.

In the observation reports, we have found no clear examples of an orientation based on personal 
interest. What can be found are descriptions of situations in which teacher educators give attention to the questions and problems of individual student teachers:

- One of Irene's student teachers: "I have been ill and a colleague has taken over my classes. Now I don't know what to prepare for tomorrow." Irene: "Call the colleague and prepare a general lesson as well, for example how to teach the pupils a popular song".

- One of Steven's student teachers: "I have been having problems with one of my classes. Together with the pupils I made an inventory of the reasons and then I drew up a contract which both the pupils and I signed". Steven: "A creative approach, but do you realize it is only one option? You could also have decided to be stricter."

However, we suspect that the attention paid to the questions and problems of individual student teachers does not always satisfy the needs of orientation based on personal interest as expressed by the student teachers. The answers given by the teacher educators seem to focus on concrete examples and practical procedures, and are not placed within a context of personal development.

Our observations did appear to confirm-at least in part - the views of the teacher educators regarding self-confidence in the student teachers (the ambivalent orientation). The majority of the student teachers had questions about problems they had encountered during practical training in schools and seemed to feel uncertain as to how to deal with those problems. This is remarkable given the fact that in the interviews the student teachers considered themselves to be highly self-confident.

In summary, with concern to a shift to studentdirected learning, we found the following positive factors:

- With regard to certificate-oriented learning, the views of the five teacher educators generally match the views of their student teachers, and the observed practices.

- With regard to vocation-oriented learning, the views of the five teacher educators match the views of their student teachers, and the observed practices.

- With regard to the ambivalent orientation, the five teacher educators make efforts to help student teachers to develop and improve their self-confidence in relation to their teaching skills.

One factor that could hinder student-directed learning is:

- Neglect on the part of the five teacher educators to devote attention to their student teacher's personal interests in the lessons, although two teacher educators (Bill and Margaret) state that they find this learning orientation equally important as vocation-oriented learning.

\subsection{Mental models of teaching and learning}

Based on our third principle for promoting student-directed learning, we assessed the mental models of teaching and learning of the five teacher educators and compared these with the mental models of their student teachers. We asked, for example, whether students learn material by heart (intake of knowledge), whether they themselves formulate questions about subject matter (construction of knowledge), whether they connect what they learn at the teacher education institute with their experience in schools (use of knowledge), whether they think about their learning methods (stimulating education) and whether they work together outside the teacher education institute (cooperation).

\subsubsection{Interviews}

The five teacher educators indicated during the interviews that they found the intake of knowledge to be one of the least important mental models of teaching and learning. Their student teachers agreed with them.

To the teacher educators the mental model of construction of knowledge was an important mental model. They valued this mental model slightly higher than the student teachers did. However, all five teacher educators said that the use of this model 'depends on whether the opportunity arises'. This is a remarkable finding, 
that elicits the question of whether the teacher educators do sufficiently plan such opportunities in a systematic manner. Again, their student teachers agreed with them. One student teacher made the following statement: "I don't make connections consciously, but sometimes I see them spontaneously".

The interviews revealed that both the teacher educators and their student teachers found that the use of knowledge, stimulating education and cooperation were important mental models of teaching and learning. We found some small differences between some teacher educators and their students. Regarding the mental model of use of knowledge, the views of four teacher educators matched with the views of their student teachers. The student teachers in Margaret's case valued the mental model of use of knowledge higher than Margaret did.

Four teacher educators valued the mental model of stimulating education slightly higher than the student teachers in the five cases did. Steven's view matched with the student teachers' views.

In regard to the mental model of cooperation we found that Irene, Rudolph, Margaret and Steven valued this model as high as their student teachers. However, Bill's student teachers found cooperation not quite so important as Bill did.

\subsubsection{Observations}

In regard to the mental model intake of knowledge, our observations confirmed the findings from the interviews: we encountered very few examples of a focus on taking in knowledge.

We observed a certain degree of the construction of knowledge in the lessons of all teacher educators. However, it was often the teacher educator who connected different knowledge sources and answered questions, etc. We found no systematic effort among Bill, Irene, Margaret and Steven and their student teachers to give attention to this mental model. Compared with the general findings for these four cases, Rudolph is an exception. He encourages his student teachers to connect prior experiences and knowledge with new knowledge by asking them questions:

- Rudolph announces a task about differentiation. He asks the students about their own experiences.
The students give examples: the smart kids at the front of the class, the less smart kids behind them, and so on.

All of the observation reports cite frequent manifestations of the use of knowledge. As described in the previous section Bill's student teachers practise what they have read and heard from Bill during the lesson. Irene's and Rudolph's student teachers practise how to make an appropriate choice between different learning methods. Margaret's student teachers reported about a lesson on philosophy they gave in primary schools. Steven stimulates his student teachers to connect their experiences with the theory on Leary's Rose.

During our observations, however, we found no common patterns in the teacher educators' practice for the mental model of stimulating education. Bill's way of teaching, recreating primary school situations, visibly invites student teachers to think about improving their own lessons. Rudolph's lessons, with their combination of challenge and putting things in perspective, sometimes in the form of a small joke, seem to stimulate the involvement of the student teachers. In the observation reports of the other cases, there is less clear evidence of stimulating education.

For the mental model of cooperation, the observation reports reveal examples of cooperation in all of the lessons observed. An example:

- Before leaving the classroom for a moment, Rudolph asks his students to form groups. It can be observed that this is not an unusual question: the student teachers know what to do. After returning Rudolph explains what to do next and adds: "think of appointing a minutes secretary, as usual".

In summary, we found the following positive factors in relation to student-directed learning:

- Regarding the mental model of intake of knowledge, the views of the five teacher educators match the views of their student teachers, and the observed practices.

- Regarding the mental model of construction of knowledge, the views of the five teacher educators generally match the views of their student teachers. 
- Regarding the mental model use of knowledge, the views of the five teacher educators generally match the views of their student teachers, and the observed practices.

- Regarding the mental model of stimulating education, the views of the five teacher educators generally match the views of their student teachers. However, the views of only two teacher educators (Bill and Rudolph) match their practices.

Findings that could hinder a shift to studentdirected learning is:

- Four teacher educators (Rudolph is an exception) neglect to give systematic attention to the mental model of construction of knowledge in their lessons.

- Three teacher educators (Bill and Rudolph are exceptions) neglect to give sufficient attention to the mental model of stimulating education.

\subsection{Reflection}

Based on our fourth principle for promoting student-directed learning, we assessed whether different reflection methods were used, whether the stage of the student teachers' development was taken into account and whether the student teachers were encouraged to reflect on different aspects of their daily experiences and their future profession.

\subsubsection{Interviews}

The five teacher educators stated that reflection on the ideas, actions and development of the student teachers took place regularly. Their students confirmed these views. However, while the five teacher educators told us that they varied their reflection methods regularly, the student teachers did not report that variety.

\subsubsection{Observations}

We observed various examples of reflection in the lessons of two of the five teacher educators, Bill and Rudolph:

- Later on in Bill's lesson, one of the small groups is discussing how fast the pupils should be allowed to run during a game, in connection to safety. Bill asks for the attention of all students: "What other actions or questions can you expect from pupils?" The students react: "Are we allowed to pass each other?", "Should we do all the tasks?", and so on.

- In the introduction of the analysis of methods, Rudolph asks the students to give examples of their own experiences with differentiation. Some examples are given. Rudolph: "These are good examples of differentiation based on knowledge, but can you also come up with other forms of differentiation?"

During the observed lessons of these two teacher educators, the method of reflection was limited to a verbal exchange between the teacher educator and the student teachers. The focus of the reflections was mainly on technical aspects of teaching.

The observation reports did not reveal examples of reflection in the lessons of Irene, Margaret and Steven.

In summary, we found the following factors that could hinder a shift to student-directed learning:

- A lack of attention for reflection by three of the five teacher educators (Bill and Rudolph are exceptions).

- A lack of variety in methods and focus of reflection.

\subsection{Congruence}

Based on our fifth principle for promoting student-directed learning, we assessed to what extent the teacher educators act as role models (teach as they preach) and explain their pedagogical choices. This principle was not covered in the interviews, but was a main point of attention in the observations.

\subsubsection{Observations}

In all five cases, we found several examples of the teacher educators functioning as role models, showing their student teachers how experienced teachers can stimulate student-directed learning. A few examples: 
- Bill shows his student teachers how to organize co-operative learning.

- Rudolph helps his student teachers to connect their own experiences with their future vocation.

- Margaret stimulates a student teacher who seems to be uninvolved, to participate in a discussion.

Only a few teacher educators, however, offered occasional metacommentary on their teaching actions. In general, the teacher educators seldom explained their pedagogical choices. In the 10 lessons we observed, we could only find three indications:

- Bill (starting the lesson): "As we discussed last time, I have marked out the spaces of a playground, a physical education classroom and a regular classroom."

- Bill (finishing the lesson): "I am more satisfied about this lesson than I was about the previous lesson, because everybody was involved. A lot of creative ideas were generated. Nevertheless, next time I would like to pay more attention to the specific needs of primary school pupils."

- Rudolph (discovering he doesn't have enough time for the lesson he planned): "Like you in your classes, I want too much. I have already learned that I want to treat too much literature, so today you will only get a small article."

Even in these three examples, one could wonder whether the teacher educators really use metacommentary on their own teaching actions to promote learning of their student teachers.

In summary, we found the following factor to promote a shift to student-directed learning in teacher education:

- The systematic effort on the part of the five teacher educators to act as role models.

One factor that could hinder a shift to studentdirected learning is:

- The almost absence of metacommentary on the part of teacher educators regarding their pedagogical choices.

\section{Conclusions and discussion}

The results presented in this article are based on small-scale, exploratory case study research. Although case studies offer a wealth of information, this information is gathered in specific situations, so we have to be very careful when drawing general conclusions. However, as Merriam (1998) and others have stated, it is possible to use the mine of information obtained in case studies as a 'working hypothesis' for comparable situations. With this in mind, we will summarize our findings and formulate a number of such hypotheses. We will also put forward some suggestions for further research.

The focus of this article is on the promotion of a shift from teacher educator-directed learning to student-directed learning among student teachers. The leading question in this article was:

Do teacher educators show the views, as well as the teaching actions, that promote a shift to studentdirected learning?

Our study was based on the five principles described in the Theoretical Background Section, that a shift from teacher educator-directed learning to student-directed learning will be stimulated if:

1. the images that teacher educators have of student teachers correlate with the images student teachers have of themselves;

2. the teaching and learning orientations of teacher educators correlate with the orientations of student teachers, and/or teacher educators stimulate student teachers to broaden their learning orientations especially in the direction of a personal interest orientation;

3. the mental models of teaching and learning used by teacher educators correlate with the mental models of student teachers and/or teacher educators stimulate student teachers to broaden their mental models of learning, especially in the direction of a view of learning as the construction of knowledge;

4. teacher educators teach student teachers to reflect regularly and variedly on different aspects of the teaching profession;

5. teacher educators act congruently: in other words, they behave as role models (teach as 
they preach) and explain their pedagogical and didactical choices (give metacommentary).

We first looked for an answer to the question of the extent to which the views on these subjects held by teacher educators promote a shift to studentdirected learning. We used interviews with five teacher educators and their student teachers for this purpose. Secondly, we examined the extent to which views on learning and teaching were expressed in the teaching actions of teacher educators. To this end, we compared the outcome of the interviews with observation results.

We found many aspects that seem to promote a shift from teacher educator-directed learning to student-directed learning. Taking into account the rapid changes in teacher education and the consequences of these changes for the tasks of teacher educators, these findings are remarkably positive.

Nevertheless, the study also revealed some aspects that hinder a shift from teacher educatordirected to student-directed learning. These findings raise questions for further research and questions regarding the professional development of teacher educators. We will discuss these questions below.

\section{General teaching competences of teacher educators}

To promote student-directed learning, teachers educators as well as teachers should have certain teaching competences. With concern to these 'general teaching competences' we formulated the principles 1, 2 and 3 . With regard to the first and second principles, we found that teacher educators rated their student teachers less highly on independent learning and self-confidence than the student teachers themselves did. The observations bring out examples of dependency not expressed by the student teachers and confirm - at least for some of the student teachers - the views of the teacher educators that the student teachers need support in order to become more independent. The observations also show that student teachers' selfconfidence with regard to their performance in schools can be improved. So, the view that the teacher educators expressed in our study about the level of independence of their student teachers seems partly realistic: the student teachers tend to overestimate their self-confidence. To promote a shift towards more student-directed learning, it seems important that teacher educators help student teachers to acquire a more realistic self-image and to become more self-confident in the classroom.

On the basis of Vermunt's studies $(1992,1997)$, we assume that a personal interest orientation (principle 2) promotes student-directed learning. In this context it is noteworthy that the interviews indicated that the students wanted more attention to be paid to their own personal development than the teacher educators offered. Although the observations showed that the five teacher educators took the student teachers' individual questions very seriously, their answers tended to focus on everyday practice and were not placed in a context of personal development.

With regard to the third principle, our study shows that in the five cases there is a different emphasis on construction of knowledge. Based on the observation results its seems that four of the five teacher educators gave less attention to construction of knowledge than the outcomes of the interviews suggested.

We conclude that in further research it could be important to raise the question how well-equipped teacher educators are to help student teachers to develop a realistic self-image of their level of independence, and to become more self-confident in the classroom. Moreover, further research should be done on how well teacher educators build on student teachers' personal interests and to what degree they emphasize the construction of knowledge in their own teaching.

\section{Specific competences of teacher educators}

As mentioned earlier in this article, the profession of teacher educators differs from the profession of teachers in at least two respects: teacher educators should not only reflect on their own teaching but must also teach their student teachers to reflect (principle 4), and teacher educators should be role models and explain the pedagogical and didactical choices they make (principle 5).

With regard to reflection no common pattern emerged in the cases we studied. We saw that only two teacher educators gave systematic attention to 
reflection. The method of reflection used was a verbal exchange between teacher educators and student teachers. No use of other reflection methods was observed and the focus was mainly on technical aspects. It is worth noting that in one of these two cases, the teacher educator was following a course on supervision. It is possible that this could be a partial explanation for the emphasis he placed on reflection.

None of the teacher educators explained their pedagogical and didactical choices systematically. Wubbels, Korthagen, and Broekman (1997) emphasize that a lack of explicit attention to pedagogical and didactical choices may hinder any significant change in the pre-conceptions about learning and teaching that student teachers already possess.

If the outcomes of our case studies should represent a more general situation, there would appear to be some problematic elements in the way teacher educators function, especially with regard to the aspects that distinguish the profession of teaching educators from the teaching profession in general. Therefore, in our opinion, the issues of promotion of reflection, congruence and metacommentary, which are characteristic for the profession of teacher educators, should get extensive attention from researchers.

\section{Promoting teacher educators' competences}

Finally, we want to draw attention to another question our findings raise: the question of how teacher educators should be educated. In the introduction to this article we mentioned that the competences of teacher educators should get more attention, a development supported by the introduction of professional standards. The introduction of professional standards for teacher educators enables us to pose questions about the extent to which teacher educators already meet these standards and the kind of support they need in order to achieve these targets. Our study provides indications that some standards will be met by most teacher educators, some by part of them and others, especially standards that are specific for the profession of teacher educators, by only a few.

If our hypothesis is correct, a combination of personal development plans and courses for teacher educators, focusing especially on the specific competences of teacher educators, may provide an effective strategy to increase the professional level of teacher educators (for an elaboration, see Korthagen et al., 2001, p. 239-253).

\section{Acknowledgements}

Wim van der Mark and Axelle de Roy collected most of the data. Axelle de Roy also assisted in the data analysis. We would like to thank both of them for their help. We also thank the reviewers of 'Teaching and Teacher Education' who gave constructive and helpful comments.

\section{References}

Buchberger, F., Campos, B. P., Kallos, D., \& Stephenson, J. (2000). Green paper on teacher education in Europe. Umea: Thematic Network on Teacher Education in Europe.

Brown, J. S., Collins, A., \& Duguid, P. (1989). Situated cognition and the culture of learning. Educational Researcher, $18(1), 32-42$.

Calderhead, J. (1987). The duality of reflection in student teachers' professional learning. European Journal of Teacher Education, 10(3), 269-278.

Claxton, G. (Ed.) (1996). Liberating the learner. New York: Routledge.

Cobb, P., \& Bowles, J. (1999). Cognitive and situated learning perspectives in theory and practice. Educational Researcher, 28, 4-15.

Cohen, L., Manion, L., \& Morrison, K. (2000). Research methods in education. London: Routledge Falmer.

Day, C. (1999). Developing teachers: the challenges of lifelong learning. London: Falmer Press.

Dengerink, J., \& Koster, B. (2000). Towards a professional standard for Dutch teacher educators. Paper presented at the conference of the Association of Teacher Educators, Orlando.

Ducharme, E. R. (1993). The lives of teacher educators. New York: Teachers College Press.

Dweck, C. S. (1989). Motivation. In A. Lesgold, \& R. Glaser (Eds.), Foundations for a psychology of education (pp. 87-136). Hillsdale, NJ: Erlbaum.

Egan, K. (1978). Some presuppositions about curriculum. Curriculum Studies, 10(2), 123-133.

Entwistle, N. (1988). Motivational factors in students' approaches to learning. In R. R. Schmeck (Ed.), Learning strategies and learning styles (pp. 21-51). New York: Plenum Press.

European Journal of Teacher Education (1990), 13(1/2). Special issue on teacher education (J. D. Wilson, Ed.). 
Furlong, J., \& Maynard, T. (1995). Mentoring student teachers. London/New York: Routledge.

Gijselaers, W. (2000). Studeren voor nieuwe Geleerden: Over de kunst van het organiseren (Studying for new scholars: On the Art of organizing). Maastricht: University of Maastricht.

Houston, W. R. (1999). Standards: the new road to quality in teacher education. In: J. J., Dengerink, J. J. F. Heins, \& M. L. Lunenberg, (Eds.), Leermeesterschap (Mastership). Leuven/Apeldoorn: VELON \& Garant Publishers.

Korthagen, F. A. J. (2000). Teacher educators: from a neglected group to spearhead in the development of education. In G. Willems, J. Stakenborg, \& W. Veugelers (Eds.), Trends in Dutch teacher education (pp. 35-48). Leuven/Apeldoorn: VELON \& Garant Publishers.

Korthagen, F., Kessels, J., Koster, B., Lagerwerf, B., \& Wubbels, T. (2001). Linking practice and theory: the pedagogy of realistic teacher education. Mahwah, NJ: Erlbaum.

Korthagen, F. A. J., \& Russell, T.(Eds.) (1995). Teachers who teach teachers: Reflections on teacher education. London/ Washington, DC: Falmer Press.

Leary, T. (1957). An interpersonal diagnosis of personality. New York: Ronald Press Company.

Lunenberg, M. (1999). New qualifying requirements for the mentoring of student teachers in the Netherlands. European Journal of Teacher Education, 22(2/3), 159-172.

Lunenberg, M. (2000). Net als jullie wil ik ook te veel in mijn lessen (Like you, I want too much from my lessons). VELON Tijdschrift voor Lerarenopleiders, 21(4), 22-27.

Lunenberg, M., \& Volman, M. (1999). Active learning: Views and actions of students and teachers in basic education. Teaching and Teacher Education, 15(4), 431-446.

Marton, F. (1990). The phenomenography of learning-A qualitative approach to educational research and some of its implications for didactics. In H. Mandl, E. de Corte, S. N. Bennett, \& H. F. Friedrich (Eds.), Learning and instruction: European research in an international context, vol. 2.1 (pp. 601-616). Oxford: Pergamon Press.

Merriam, S. B. (1998). Qualitative research and case learning applications in education. San Francisco: Jossey-Bass Publishers.

Miles, M. B., \& Huberman, A. M. (1984). Qualitative data analysis. London: Sage.

Richardson, V. (1999). Teacher education and the construction of meaning. In G. Griffin (Ed.), The education of teachers (pp. 145-166). Chicago: The University of Chicago Press.
Stofflett, R. T., \& Stoddart, T. (1994). The ability to understand and use conceptual change pedagogy as a function of prior content learning experience. Journal of Research in Science Teaching, 31(1), 31-51.

Ten Dam, G. (1989). Vrouwen verschillen in de volwasseneneducatie (Women differ in adult education). Amersfoort/ Leuven: Acco.

Ten Dam, G. (1995). Dropout from adult education. International Journal of Lifelong Education, 14(1), 51-63.

Van der Vaart, W., \& Lunenberg, M. (1996). Kwalificaties van mentoren en docenten (Qualifications of mentors and teachers). Amsterdam: IDO/VU.

Vermunt, J. (1992). Leerstijlen en sturen van leerprocessen in het hoger onderwijsnaar procesgerichte instructie in zelfstandig denken (Learning styles and learning processes in higher education: Towards process-oriented instruction in independent thinking). Lisse: Swets \& Zeitlinger.

Vermunt, J. (1997). Leeractiviteiten van studenten (Learning activities of students). In G. Ten Dam, H. Van Hout, C. Terlouw, \& J. Willems (Eds.), Onderwijskunde Hoger Onderwijs (pp. 30-45). Assen: Van Gorcum.

Vonk, J. H. C. (1995). Teacher induction: An essential element at the start of teachers' careers. Revista Española de Pedagogia, 53(200), 5-22.

White, B. Y., \& Frederiksen, J. R. (1989). Designing articulate micro-worlds that facilitate learning, understanding, and problem solving in science education. Paper presented at the Annual Meeting of the American Educational Research Association, San Francisco.

Wideen, M. F., Mayer-Smith, J., \& Moon, B. (1998). A critical analysis of the research on learning to teach: Making the case for an ecological perspective on inquiry. Review of Educational Research, 68(2), 130-178.

Wood, E., \& Geddis, A. N. (1999). Self-conscious narrative and teacher education: Representing practice in professional course work. Teaching and Teacher Education, 15, 107-119.

Wubbels, T., Korthagen, F., \& Broekman, H. (1997). Preparing teachers for realistic mathematics education. Educational Studies in Mathematics, 32, 1-28.

Yin, R. K. (1994). Case learning research: design and methods. London: Sage.

Zimmerman, B. J. (1990). Self regulated learning and academic achievement. American Educational Research Journal, 25, 3-17. 